Ladislav CABADA*

\title{
NATIVIST AND ANTI-LIBERAL NARRATIVES IN CONSERVATIVE POPULIST AGENDA IN CENTRAL EUROPE**
}

\begin{abstract}
Nativism does not only present a concept, but also an ideological framework as well as a political practice related to identity politics. In the article we firstly present the theoretical reflection of nativism and operationalise the most important terms and characteristics of this phenomenon. Later, we apply the concept of nativism to the analysis of conservative populist and/or nativist political actors in the Central European region. The analysis shows how nativism, as a relatively peripheral issue in the first 10-15 years after the democratic transition, became stronger in the next period characterised by a set of crises after 2008. The analysis demonstrates how the mainstream parties in Central Europe adopted the nativist and conservative populist agenda and implemented it into mainstream politics. Furthermore, the analysis shows how Central European nativism correlates with the long-term existence of antiliberal streams that were revitalised after the fall of Communist regimes. These anti-modern societal groups were reformulated as the counter-cosmopolitan camp within the polarisation process that is clearly visible in the political arena.
\end{abstract}

Keywords: nativism; national conservatism; identity politics; Central Europe

\section{Introduction}

On 29 November 2017 Cambridge Dictionary's Word of the Year 2017 was declared - populism. In the commentary to this choice, the inauguration of the $45^{\text {th }}$ President of the United States, Donald Trump, is mentioned

* Ladislav Cabada, PhD, Associate Professor, Department of Politics and Humanities, Metropolitan University Prague, Czech Republic.

** This article is the result of Andrássy Gyula Deutschspracihgen Universität Budapest and Pallas Athéné Domus Educationis Stiftung research project DonAUB (2020).

DOI: 10.51936/tip.58.2.284-304 
as one of the key events and symbols for such a decision. In the short commentary it was stressed that populism 'represents a phenomenon that's both truly local and truly global, as populations and their leaders across the world wrestle with issues of immigration and trade, resurgent nationalism, and economic discontent' (Cambridge Words, 2017). Reflecting upon this decision, Cas Mudde (2017) proposed that nativism, not populism, should be declared because the arguments Cambridge Words used for populism are not in scope with the basic definition of the term - separation of societies into two antagonistic groups, 'the pure people' vs 'the corrupt elite' but perfectly fit the definitions of the far right and even more the definition of nativism.

Nativism, historically associated with the premodern period, has become an important component of contemporary politics. Similarly, as in the cases of previous waves of nativism, the contemporary situation also has the characteristics of a revitalisation movement against openness, modernity and more general globalisation. Nativist actors stress the necessity to promote the interests of native inhabitants and tend to prefer social chauvinism practices, economic protectionism and even autarky, successfully securitise the migration issue and develop the historical narratives based on national populism, traditionalism, anti-modernity and anti-liberalism. The proponents of nativism also skilfully include the traditional instruments of populist and far right actors such as anti-EU stances, invoking 'normality' regarding gender and family issues, etc.

The West seems to be undergoing a strong wave of traditionalism, undermining important narratives and structural parts of its (post)modern situation such as individual freedom, general equality, free market etc. Alongside other impulses (regarding the EU, especially the institutional crisis and enlargement incapability since the mid-2000s), the fiscal and economic crisis after 2008 changed the situation dramatically. As Klíma (2020) shows, this juncture was provided by electoral earthquakes and the establishment of second post-transitive party systems. Next to the anti-corruption rhetoric the new actors also used anti-European and nationalist narratives based on criticising the catching up process as a failure.

This period was already accompanied by the politics of emotions, above all fear from the renewal/consolidation of a peripheral position of EastCentral Europe (ECE) in the European architecture. Contrarily, in Western Europe the economic crisis strengthened the doubts about the prospects of the all-European Integration Project (Ágh, 2019: 44-46). Furthermore, the next juncture - the migration crisis in 2015 and beyond - further strengthened these feelings and brought a new wave of patriotism, nationalism and xenophobia into politics and societies. As Klíma (2020: 158) stressed: 'The immigration issue indeed covers a cultural identity conflict, or a 
fundamental security dimension, incorporating a highly emotional component in the form of fear'.

Especially since 2015, national populist actors have been strengthening and, in many cases, we can observe their important electoral successes. Next to the election of $\mathrm{D}$. Trump we have to mention the success of J. Bolsonaro in Brazil, the Brexit issue, the electoral success of national populist parties in the United Kingdom, France or Italy, as well as the stabilisation of these parties in some ECE states. The former pariahs of European politics - V. Orbán and J. Kaczyński - present themselves as 'authentic Europeans' criticising the 'weak, (ultra)liberal Brussels' and appealing for a cultural counter-revolution in Europe. The polarisation of Europe and Western societies continues and almost any new electoral campaign and result brings a new round of debates about this polarisation and clashes between two distinctively different political camps promoting (and growing from) distinctively different and competing political cultures.

\section{Rationale of the article}

The aim of this article has to be reduced from general debate and analysis of nativist restoration in the world to less extensive goals. Firstly, I will reduce my analysis spatially and focus on the development in Central Europe. Nations of the Visegrad group and Slovenia are usually included in Central Europe by contemporary political scientists (cf. Ágh, 1998; Ágh, 2019; Cabada and Walsch, 2019; Fink-Hafner and Haček, 2000). Despite different development after WWII, Austria is also often included in Central European comparisons (Cabada and Walsch, 2019; Hloušek and Kopeček, 2004). For the group of the six mentioned nations I will apply the concept of nativism searching for manifestations of a nativist approach and policies. I will search for actors using nativist rhetoric and strategies as well as for the most important themes and paroles used by Central European nativists. Furthermore, I will analyse the overlap in Central European nativist performance and also their cooperation. I assume that nativism in Central Europe is strongly related to the unfinished and deformed modernisation processes. From this presumption I derive the first thesis: The cultural conflict (clash of cultures) that arose in Central Europe during the process of modernisation, lasted out the period of the non-democratic regime after WWII and was revitalised after 1989. Based on this thesis I ask the first research question: Does the contemporary nativism in Central Europe grow from visible and shared anti-liberal legacies? In the first 10-15 years of democratic consolidation the anti-modern and/or nativist actors were marginalised within the processes of socialisation, Westernisation and Europeanisation. The grand narrative of the 'Return to Europe' raised 'general' optimism in Central European 
societies and the proponents of 'counter-cosmopolitanism' were relatively weak in this period. Nevertheless, after the mid-2000s the nativist ideology and national populism as a political strategy has been revitalised and transformed from being relatively peripheral in politics and society to being the political mainstream.

On one hand, I presuppose that the small parties usually located outside the mainstream used the nativist and conservative populist agendas which existed before the important junctures of 2010 (earthquake election) and 2015 (migration crisis as a new impulse for the poly-crisis situation). On the other hand, I presuppose that the mainstream parties started to use similar strategies and rhetoric only after 2015 due to tactical reasons. The situation might differ in individual countries, but in all cases I assume the combination of ideology and strategy by the mainstream actors while the 'original' nativists were gained by these new mainstream nativist actors, or pushed again to the margin of the political arena. From these presumptions I derive the second thesis: After 2004, the mainstream parties in Central Europe often labelled as national-conservative marginalised the traditional nativist formations and/or adopted their ideology, programme and strategies. Based on this thesis I ask the second research question: Are we observing the general mainstreamisation of the nativist issues and strategies in Central European political arenas? In the first part of the analysis, I will operationalise the general terms such as nativism, national populism, xenophobia, autarky, etc, and frame this terminology with two big concepts. From the best described case of nativism (United States/North America) I will derive the main terms and concepts into the more general framework for political science analysis. Secondly, in the case of ECE I will present the process of unfinished or deformed modernisation and the revitalisation and re-modification of the clash of cultures (Kulturkampf) in the last 30 years. In the second part I will apply this theoretical framework to the Central European case.

The article is rooted in comparative analysis, combining the synchronic and diachronic approach and focusing on the development of political parties with nativist tendencies in ECE. Based on the two theses or assumptions presented above I focus on the development of party politics and those parties that advance the nativist attitudes. In the political discourse of individual countries, I search for typical strategies, signs and terms of the nativist narrative such as the systematic criticisms of minorities, cultural and other types of racism, moral disqualification of 'the other', idealisation of peasantry, peasant life and common sense, support of majoritarian democracy tools, above all plebiscites, the concept of naturalness, emphasis on patriotism and 'correct' European values and 'Christian Europe', etc. Behind the national discourses I then search for similarities and shared strategies of nativist actors, as well as mutual reasons for their strengthening. 


\section{Nativism as concept, social phenomenon and program of identity politics}

As already mentioned, the phenomenon of nativism is strongly interconnected with the development in North America and ethnogenesis ${ }^{1}$ of the 'native' (North) American nation. Katerberg (1995: 495) describes nativism as an 'umbrella term traditionally used by North American scholars to describe anti-Catholic, anti-immigrant, racist and antiradical agitation ... Like nationalism, it originates in common customs religion and ethnicity' (Katerberg, 1995: 495). As the symbolic and general expression of North American nativism, the abbreviation 'WASP' is usually mentioned, stressing the exclusive position of the English language and predominance of AngloSaxon or protestant cultural values and institutions (Simcox, 1997: 132). Barša and Císař (2006: 417-419) describe the development of the nativistrooted American nation as the ethnicisation of a folk community of settlers that led to the 'nativist' image of America as the country of the descendants of the original immigrants in the $17^{\text {th }}$ and $18^{\text {th }}$ centuries, but not the land of contemporary and future immigrants. As an important political actor rooted in this conviction, they mention the seventh U.S. President Andrew Jackson. 'Jacksonians' are rooted in evangelical Christianity stressing their own root to God. They regard the human being as limited and prone to 'sin'. Often, they consider the world endangered by dark powers - the Catholic Church, global Communism and recently the global 'Islam'. Particularism and isolationism are typical segments of their thinking.

Let us stress two important facets in this basic definition of nativists - xenophobia and the idealisation of the traditional pre-modern society rooted in agrarian and a rural/small town lifestyle. Simcox (1997: 30) stresses that 'xenophobia and racism are concepts often subsumed in the general concept of nativism'. Together with anti-Catholicism ${ }^{2}$, xenophobia and racism are usually reflected as the most important patterns of American nativism (Friedman, 1967: 408-409). As Sundstrom (2013: 80) underlines, 'xenophobia is conceptually prior to nativism' and nativism 'indicates a positive political project to actively exclude or expel those judged to be too foreign to belong, or to hoard the national community's resources and keep them from being exploited by foreigners' (Sundstrom, 2013: 72). Nativism is centred on the 'us first' idea, it is rooted in the fear that strangers will undermine

1 We understand the ethnogenesis as the 'individual seek to achieve a measure of belonging and terrestrial immortality through identification with a group rooted in land and kinship' (Kaufmann, 1999: 444-445).

2 Catholicism was depicted as a false religion and danger to the United States. 'From 1820 onward, the notion of Americans as genealogical descendants of Englishmen also gained in currency' (Kaufmann, 1999: 446). 
the traditional way of life (Crepaz et al., 2014: 943). Nativism is most often associated with anti-immigrant sentiments motivated by ethnic or racial bias (Bosniak, 1994: 442-443).

Let us acknowledge the second above-mentioned aspect - traditionalism and idealisation of the pre-modern societal structure. Nativists prefer and force a 'traditional version of American culture' (Knoll, 2013: 153). Nativism evinces typical conservative positions stressing the degressive development of humankind. Often, we can observe the idealisation of the 'Golden Age', idealisation of peasantry and rurality, and rejection of modernisation. Here we have to stress the paradox that nativism grew out of roots similar to that of communitarianism, both stressing the importance of Gemeinschaft. As Crepaz et al. (2014: 943) stressed:

What nativism and civicness both have in common is an emphasis on community: nativists see their own culture and ways of life threatened by foreigners, while others argue that a decline in civic behaviour will undermine the very foundations and working of democracy.

If we analyse the contemporary debate about nativism through the lenses of philosophy, we can find an important overlap of this 'nostalgic' concept with a selected environmental stream, especially deep ecology and ecopolitics (Mathews, 1999: 253-255). Namely, in many aspects the nativist stance rooted in deep ecology shares the criticism against the (post)modern society. To distinguish the 'reactionary' political nativists and the ecopolitical nativist, I use the term 'eco-nativists' for the latter. Regarding urbanisation, eco-nativism stresses the negative consequences of rapid urbanisation and industrialised agriculture. Against this development eco-nativists present the 'ideal of the native self' related to small rural or semi-rural sustainable communities. Furthermore, eco-nativists stress the necessity of spatial identity related to geographically small units, the necessity to belong to a place, 'to have one's identity shaped by the place to which one belongs' (Mathews, 1999: 245). The idealised 'home' presenting the small community should develop the eco-nativist self-identity (Storey, 2012: 11) rooted in care and maintenance of nature.

Both types of nativism negate the modernity related to the creation of open society (Bergson, 1936; Popper, 2011) in a political but also broader societal and cultural sense. As one of the inherent characteristics of an open society is the opening and removing the borders, nativists defend the juxtaposition and promote the 'ideal' of a closed society. Next to open borders, mobility is also considered a negative sign of modernity and is attacked. The nativists especially deny 'immigration', while the eco-nativists deny mobility, especially tourism, entirely (Mathews, 1999: 247). Nevertheless, 
both types of nativists negatively regard 'extensive' mobility and the blending of (groups of) people with different identities. In their opinion, such 'openness' undermines the 'state of indigeneity'. In this sense the nativists are strongly interconnected with the theories of 'rise and fall' (Kennedy, 1987) or theoretical works about the collapse of states or civilisations, more precisely with those who stress the amalgamation of societies as one of the more important or even dominant reasons. ${ }^{3}$

Indeed, eco-nativists propose the voluntary limitation of mobility accentuating that the new communication technologies create the 'awareness of a larger frame' and prevent the ecological nativists from 'narrow-minded parochialism, xenophobia, or exclusionary thinking' (Mathews, 1999: 267). In contrast, the 'traditional' nativists promote (neo)parochial political culture as the ideal. Their negative perception of (post)modernity creates a vital potential for revitalisation programmes and activities with clearly reactionary contents. Katerberg (1995: 501) labels the repeated waves of nativism as 'crusades' attempting to 'reassert what are held to be traditional customs, values, and practices'. As an important stimulus for such waves the author observes the fear that 'heterogeneity would destroy their ability to perpetuate their values, traditions, institutions, and laws' (Katerberg, 1995: 508).

Reflecting the North-American development, the first and by far the most important and verbalized expression of nativism was a broad fear that the large mid-century (18 century - quoted by L.C.) influx of Germans would not be assimilated into the dominant English racial culture, and that Pennsylvania therefore might become eventually a German colony'. The fear of Germanisation was even strengthened with the obsession 'that Germans would convert to Catholicism and then unite with French against the English' (Friedman, 1967: 411-412). Another wave came in the 1820s and beyond (the already mentioned 'Jacksonians' (Kaufmann, 1999: 455/) negatively reflecting the 'Catholic' population of the United States. At the turn of the $19^{\text {th }}$ and $20^{\text {th }}$ centuries the 'defenders of the Anglo-Saxon roots of Canada and the United States feared that immigrants of inferior racial stock, from southern and eastern Europe, would dilute the quality of American and Canadian blood, corrupt society, and threaten democratic order' (Katerberg, 1995: 506).

As we can observe, the 'aliens' change during this time, but the main characteristics of North American nativism were protected. The 'aliens'

3 Let us quote from Mathews (1999) who belongs to the eco-nativist authors, but paradoxically shares important positions with the xenophobian political nativists: 'Being native is an existential condition which imperial civilisations such as Rome, but even more particularly those of Europe in the modern era, tend to render obsolete ... The state of indigeneity becomes more and more attenuated amidst the flux of peoples and cultures and economies that imperial regimes, particularly those of modernity, entrain (Mathews, 1999: 244). 
should generally represent two kinds of threats. 'Immigration usually is said to represent two kinds of threats to this country (the United States - quoted by author). First, there is a threat posed by the identity of the immigrants ... Second, immigration is said to cost too much - economically, environmentally and socially' (Bosniak, 1994: 440). In this sense, also theoretical works on nativism differ - while some authors stress the economic competition (Friedman, 1967: 410; Simcox, 1997; Druxes and Simpson, 2016); the other group prioritise the cultural dimension. For example, Kaufmann (1999: 437-438) has doubts about the economic reasons for nativism stressing that the 'outbreaks of nativism /the 1920s, for example/ have tended not to correlate with poor economic times'. Similarly, Katerberg (1995) discusses the search for identity and cultural loyalty as the primary motivation of nativists.

The scholars often stress 'exceptionalism' as an important component for this concept. America was described by the Puritans as 'new Canaan, or the promised land' (Kaufmann, 1999: 441). Among others, millenarian movements and churches used the term 'New Jerusalem'. After the 1840s the belief that WASP-settlers were destined to expand across all of North America created the platform for the so-called manifest destiny. An important part of this exceptionalism was the 'global mission' the U.S. often stressed, including the role of leading soft power. As recent analysis of the Trumpian period of nativism has stressed, this role was abandoned. Furthermore, the global expansion of English created a situation where 'aliens' speak English along with their native languages, while Americans, living in the 'American glasshouse', do not learn foreign languages (Krastev and Holmes, 2020: 184-186).

To summarise, nativism might be understood as a social phenomenon and political program as well as a concept. Nativism could be understood from very different perspectives - for example philosophy or linguistics could reflect it in a 'neutral' manner, while social sciences mostly stress the negative influence of nativism as a political strategy on democratic development. For my research the most important question is how far - and if - the concept of nativism might be applied in a different environment than North America. As presented, the (North) American nativism was born in a very specific situation and also (some of) its characteristics are unique. Nevertheless, I am convinced that many of these characteristics might be applied as general features observable in other societies including the Central European nations.

\section{Anti-modern and nativist legacies in Central Europe}

Since the beginning of the democratic transition in ECE, scholars have been discussing the question of a specific political culture of the nations in 
this region. One of the main issues discussed is the limited, partial, unfinished and/or deformed modernisation in comparison with the European West. Sztompka (1993) talked about the 'fake modernity' in Eastern Europe after WWII, Bernik (1997) about the 'submodern society', both scholars stressing the top-down character of such 'modernity' unrooted in civil society.

After the fall of Communism, the 'grand narrative' of unfinished modernity and an anti-liberal notion was challenged by a new narrative of liberal democracy. Anyway, as the 'alternative' or 'parallel' model in only partially or defectively modernised societies, the traditional anti-modern narratives were developed too. The civil society in ECE often survived the Communist period in the form of a rather 'bad civil society' or uncivil society. In times of crisis such an uncivil society becomes a strong supportive vehicle for the populist politicians stressing the 'glorious past', 'national interest', 'normality' or 'the right and duty to oppose the political correctness of Euro-elites'. As Corbea-Hoisie (2013) stresses, the interconnection of different anti-Communist movements and pre-Communist anti-liberal and anti-modern narratives might be observed in ECE. He is talking about the 'camouflaged continuity' of these movements after the transition.

The issue of development and modernity in the formation and identity of different European nations is raised by many scholars and observers. Since the Enlightenment period, two different ideal types - the 'West' and the 'East' - as the European macro-regions are presented based on different cultural patterns. Between these two macro-units the 'in-between' area is often situated, namely Central Europe playing the role of the 'Western periphery' or the transitive region between the West and East. For example, Hofmannsthal labelled the Central European population and the citizens of the Habsburg monarchy 'semi-European and semi-Asian nations' (Kożuchowski, 2013: 86). At the end of the 19 ${ }^{\text {th }}$ century, Hope (1894) took a similar position when introducing the concept of Ruritania: a Germanspeaking, Catholic land in Central Europe, an absolute monarchy driven by deep social conflicts where the most important tension was between the (almost) western urban elites and the rural ethnics settled as the (semi-) peripheries. Similarly, Gellner $(1998,2008)$ places the Habsburg monarchy at the epicentre of the decisive modernisation conflict between the cosmopolitan liberals ('the Viennese') and the representatives of 'post-feudal obscurantism and authoritarianism'.

I assume that this phenomenon of a 'clash of cultures' is still present in Central Europe, or - in other words - that the totalitarian period as well as three decades of democracy building did not surmount or erase the anti-liberal political culture rooted in nativism and (ultra)conservatism. Despite the revolutionary rhetoric, the Communist regimes were often rooted in conservative postures, especially regarding the issues related to postmodern 
values (one example is the very restrictive policies regarding the LGBT communities and/or induced abortion in many states of the Soviet bloc). Also, nationalism was very strong in Eastern Europe, based on the violent homogenisation of local populations during and immediately after WWII, as well as the almost impermeable borders and lack of contact with the representatives of other ethnicities, nations or cultures. Such 'mental introversion' became even stronger with the demolition of liberal streams and mass emigration from the region. As depicted by Kitschelt (2003) in his typology of Communist regimes, Central European Communism also did not constitute the modernisation factor, or if so, only partly.

In 1989, a juncture came with the fall of the Communist regimes and the beginning of the democratic transition. EU-membership as the second juncture presents the symbolic end of the 'accommodative' period when the new democracies in ECE underwent important changes in economic, political and institutional sectors. Nevertheless, these changes also restored the internal divisions in the societies - usually we label the two ideal typical societal groups as 'winners' and 'losers'. ${ }^{4}$ Specifically, 'the boundaries between the rural and urban have remained porous in Eastern Europe, as they were under socialism' (Buzalka, 2008: 760). The reason is the massive influx of rural populations to the cities after WWII that preserved the 'rural' narratives, morality, imagery and ideology that might be more or less equated with Hope's or Gellner's concept of Ruritania. With the exception of Czechia, such a 'rural' narrative is also strongly interconnected with religiosity (Buzalka, 2008: 762-768).

I assume that the anti-modernists, facing new challenges in the form of the postmodern European community and globalisation, were relatively passive during the 1990s, suppressed by the new (neo-)liberal political actors pragmatically bringing their nations into the EU. Nevertheless, in the beginning of the 2000s we already saw the anti-European streams in ECE nations, often also using anti-modern and nativist rhetoric. Usually these actors were relatively weak and positioned outside the political mainstream, but some of the mainstream parties capitalised on such a narrative (Czech Civic Democratic Party /ODS/ under the leadership of V. Klaus might be a good example). Some of these actors achieved success in the second-order elections (League of Polish families in 2004 EP-elections), and some of them were invited into the governments.

The wave of the so-called earthquake elections at the turn of the 2000s and 2010s changed the situation. Many newcomer parties presented the national populist rhetoric, and also some of the established mainstream

4 For example, Ther (2014: 20) presents the dichotomy rich cities vs. poor countryside, while Ágh (2020) speaks about the well-developed 'European' cities and backward countryside. 
parties developed the nativist segment in their policies. If we analyse the important social cleavages related to the above-mentioned segmentation of societies into the 'winners' and 'losers' camps, at least three important cleavages should be mentioned, playing important and even decisive roles in the polarisation of these societies.

\section{Table 1: STRUCTURING CLEAVAGES IN CEE DEMOCRACIES}

\begin{tabular}{|l|l|}
\hline $\begin{array}{l}\text { support of post-national political institutions } \\
\text { (for example, EU) }\end{array}$ & $\begin{array}{l}\text { opposition to post-national political } \\
\text { institutions (for example, EU) }\end{array}$ \\
\hline free (global) market allocation & economic redistribution or protectionism \\
\hline $\begin{array}{l}\text { liberal-cosmopolitan values and recognition } \\
\text { of cultural diversity (secularism) }\end{array}$ & $\begin{array}{l}\text { authoritarian conformism, social cohesion } \\
\text { and cultural homogeneity (including } \\
\text { clericalism) }\end{array}$ \\
\hline
\end{tabular}

Source: Rensmann, 2012: 77.

All these cleavages are directly related to the nativist question. While the proponents of the stances presented in the first column might be understood as 'cosmopolitan liberals', the defenders of positions described in the second column tend to national or even nativist postures. Rensmann (2012) suggests labelling them as 'counter-cosmopolitan'. In his opinion, this term

294 better describes the basic position of anti-modernist societal groups in Central Europe and also opens the possibility of reflecting the nativist tendencies outside of a concrete ethnical/national environment. As he stresses, both the 'nativism and counter-cosmopolitanism are generally non-inclusive orientation', but there exist some differences. While nativism is 'limited to territorial substrates', counter-cosmopolitanism 'can also be grounded in religious ... or broader cultural references' (Rensmann, 2012: 75).

Counter-cosmopolitanism

refers to the general opposition to all social processes associated with existing globalization. Counter-cosmopolitanism is neither limited to welfare protectionism nor "single-issues" such as anti-immigrant policy; rather, it combines opposition to: 1) socioeconomic globalization and the global capitalist market economy; 2) cosmopolitan cultural transformations, signified by increasing cultural diversity and hybridity ...; and 3) political transformations associated with global and post-national governance. (Rensmann, 2012: 74)

In fact, the author reflects counter-cosmopolitanism as the contemporary position, but one rooted in historical legacies with clear nativist features.

Nativist politicians are able to flexibly change the 'enemies' as well as combine them and squeeze them under one constructed label. So, the Hungarian Fidesz and Polish PiS share irreconcilable positions against the Left, liberals, 
intellectuals, 'old networks', the EU and other transnational activities and structures including the general principle of globalisation (Fehr, 2016: 25). One of the symbols of the nativist attack against open society equated with globalisation became the Hungaro-American philanthrope George Soros, attacked not only by the national conservative actors in Central Europe, but also by the declaratively left oriented populist actors such as Slovakian Prime Minister R. Fico and Czech President M. Zeman (Matulík, 2019).

The nativists successfully addressed the societal groups that were - objectively or subjectively - negatively economically affected during the transformation process. Usually they presented the minor and 'radical' actor next to the mainstream populist party or parties that also stressed the 'protection of the poor' - let us stress the co-existence of PiS and LPR in the Polish government in 2005-2007 or the repeated cooperation of the Slovakian party Direction - Social Democrats (Smer) with the Slovak National Party, as well as the cooperation of the Slovenian Democratic Party (SDS) with the NSi. Similarly, Liehbart (2020) also comments on the government cooperation of the Austrian People's Party (ÖVP) and FPÖ. Often, the government and the mainstream party (partly) adopted the rhetoric and strategy of such minor actors, in some cases erasing them as the relevant party.

Nevertheless, what is more important for my analysis is the fact that during this period, the national populist actors reformulated and 'completed' their programme. As Ágh (2020) shows, these actors champion the politics of past and historical memory, including the (re)construction of historical narratives. The nativists formulated the 'traditionalization' narrative about the 'glorious past that never was', remembering the 'Golden Age' of national history. Let us mention here that the 'pre-communist past of these countries often coincides with ultranationalist or fascist experiences that emphasized national unity, both spiritual and territorial' (Pirro, 2014: 604). The interwar political regimes in Austria, Hungary, Poland, Yugoslavia, the Baltic states or Romania developed in a strictly anti-liberal course and were not capable of developing more than a temporary 'façade democracy'. Historical reflection of interwar regimes in many Central European nations led to the 'resurgence of neoromantic, populist, anti-modern forces in the region ... In all these societies, movements and parties have emerged that romanticize the past and idealize authoritarian traditions' (Tismaneanu, 1998: 3; cf. Pirro, 2014: 603). An important part of this construct is also the mythicisation of the pre-Communist state of affairs, associated with the exile - this narrative plays an important role in Slovenia (Šori, 2015), Croatia and also Bulgaria and the Baltic states.

Analysing the most important legacies influencing this process of (re) construction of historical narratives, Pirro (2014) presents a set of pre-communist, communist and post-communist issues. In the first group he stresses the predominant role of irredentism and clericalism. The "combination of 
nativism and Christianity generally tends to reinforce the "us versus them" contraposition' (Pirro, 2014: 606). Presenting the history of the American nativist, we mentioned the key role of anti-Catholicism. Let us stress that the construct of Judeo-Christian society presents one of the keystones of WASPnativism (Cainkar, 2007: 10), as well as an important part of the European narrative. Despite the partial changes regarding the North American development ${ }^{5}$, the development in the last decade shows that Huntington's 'American Creed' that 'is impregnated with Protestant rather than universally Christian morals' (Weidinger, 2017: 60) still presents the main ideological frame for the activities of such movements as the Tea Party, combining traditionalism, localism and racism.

In Europe, a similar process of combining nativism with orthodox Catholicism might be observed, as Buzalka (2008) stressed analysing the LPR, and its activities within the government led by PiS after 2005. Doubtless, the nativist groups in contemporary Europe stress the 'Christian Europe' concept, while this group of 'defenders' of Christian roots of Europe often includes such divergent actors as the ultraconservative 'mystic' J. Kaczyński and the former Social Democrat M. Zeman that developed after 2013 as the President of Czechia into the new 'national-conservative' role of 'defender 296 of Christian Europe'. As Weidinger (2017: 63-65) stresses while analysing the switch of the Austrian FPÖ from liberal-national towards 'belonging without believing' and 'Christendom above Christianity' positions, Zeman and similar politicians (mis)use the rhetoric of defending the Christian values to win the support of nativist-minded voter groups.

Naturally, churches often present themselves as important institutions defending 'traditions' and present important actors in politics. Nevertheless, in the case of Central Europe we can also observe another important tradition that is similar to the development in the U.S., namely the nationalisation of the church/es. It is more than clear that the Polish Catholic clergy strongly oppose the 'modernisation' of the contemporary Pope Francis; the same might be said about the tendencies in the Slovenian and Croatian Catholic clergy. We can similarly evaluate Czech Catholic officials, also supplemented by the existence of the national 'Hussite Church' with strong nativist tendencies (Cabada, 2019: 126-130). The church/es are playing an important role also in political decisions regarding family issues (marriages of same sex persons), perception of the LGBT community members and gender issues in all of ECE. Nativist actors in Bulgaria (Ataka) propose the

5 While earlier waves of American nativism featured strong anti-Catholic sentiment, combining religious and racist (White nationalists) motives, the explicitly anti-Catholic ticket is not available to nativists anymore: Catholicism is now the biggest single congregation in the United States, and Catholics hold key positions within the Christian Right. However, the equation of "Protestant religious identity with being American" is still championed by relevant actors' (Weidinger, 2017: 56). 
endorsement of Christianity as the state religion, both Fidesz and the Jobbik Party present Hungary as a country based on Christian moral principles, the Slovak National Party as well as LSNS promote the national, Christian and social principles (Pirro, 2014: 612).

As regards the communist issues, Pirro (2014: 608) stresses two important legacies - social national economics and anti-Communism. As regards the first, he stresses the 'buy national' movements as well as domestic production and agriculture (Pirro, 2014: 615). The contemporary Covid19-crisis even strengthened such tendencies including the calls for 'food autarky' declared by the Czech government and generally the tendencies towards economic protectionism. The process of constructing the new national bourgeoisie in Hungary is also well described (Ágh, 2019). Nevertheless, for nativist politicians the most important issue seems to be the media. In Hungary, the process of nationalising the media scene is almost completed. Immediately after the second round of presidential elections in Poland, the leader of PiS J. Kaczyński declared the next main goal to be the 'repolonization' of the media market, including the preparedness of the government to buy the media from foreign owners. Furthermore, we can also observe in Central Europe an important switch from 'public' towards 'national' media that could broadcast patriotic news. It's not only in the case of the media that we observe among the Central European nativists hostility towards foreign capitals and anti-EU, anti-Western or anti-German ${ }^{6}$ sentiments (Rensmann, 2012: 86).

As regards the anti-Communist legacy, it became one of the key instruments of nativist actors to delegitimise their political opponents. Usually, anti-Communism is combined with anti-intellectualism and anti-liberalism, i.e. the intellectuals and liberals are generally presented as leftist and the left is presented as post-Communist (issue of continuity) and even collaborating (Fehr, 2016: 24-27). Kaczyński, Orbán, Janša as well as the leaders of Slovakian nativist parties invented de-Communisation as an important theme of conflict and framed this theme with the paradigm of a national conservative counter-revolutionas Kaczyński and Orbán labelled their goal in 2016 at their meeting in Krynica (Anderson, 2016) - rooted in moral revolution, re-traditionalisation and anti-modernisation (Fehr, 2016).

As the most important post-Communist legacy, Pirro (2014: 608) depicts the minority issues as the 'variant of nativism in post-communist countries'. During and after WWII Central Europe underwent dramatic demographic

6 As Fehr painstakingly shows in the analysis of the 2012/13 Czech presidential campaign, the national conservative actors can also team up effectively with leftist populists or radicals in some countries - in Czechia with the Communist Party. Throughout the campaign, M. Zeman was billed as a 'genuine Czech' in a showdown with the 'non-Czech' K. Schwarzenberg. National conservatives, Fehr stresses, here play the same cards that the Communists relied on before the transition: In both Poland and the Czech lands, hatred of the Germans was the Communists' last hope' (Fehr, 2016: 114). 
changes and both absolute and relative ethnic homogenisation. The situation of closed or semi-closed borders even strengthened the 'ethnic isolation' by including the mistrust and fear of other nations. The fear caused by otherness remains an important feature in the region. In domestic politics we often observe anti-Romani rhetoric, as well as repeated anti-Semitic postures. While in the case of an anti-Communist legacy Austria cannot be included into the comparison, in the minority issues the FPÖ might be understood as a trend-setter for the Central European nativists, especially after 2015. Similar to the case of the FPÖ, the nativist actors in ECE developed the combination of anti-migrant and Islamophobic rhetoric stressing the need to protect the 'Christian character' of Europe (Weidinger, 2017: 42).

An important additive in the nativist discourse became Christian allusions combined with the conviction that Central European nations historically saved the Christian West from the menace from the East (Turks, Russians) (Weidinger, 2017: 41). Furthermore, the populist and nativist actors from ECE present themselves as the saviours of European 'Christian' / traditional values before the 'ultraliberal' and declining West ('Brussels'). V. Orbán and J. Kaczyński repeatedly stress that if the West wants to survive, it has to imitate the 'East', i.e. them, the Visegrad Group and in general the ECE populist nativists (Krastev and Holmes, 2020: 59).

Next to religious and/or national minorities, the nativist actors also assault other minorities - typically the LGBT community and women, often using the strategy of moral disqualification. As Šori (2015) demonstrated in the example of the New Slovenia (NSi) party, the nativist and (ultra)conservative arguments are usually mixed. The LGBT community is accused of diminishing the normality and negatively contributing to the demographic decrease in Europe that immediately provokes the next negative issue immigration. As regards the 'female issue', nativists often stress the 'natural' role of woman as mother and criticise the (post)modern individualism that leads to the abandonment of this 'natural' role.

\section{Discussion}

As our analysis shows, in the last decade we have observed a dynamic development in ECE. Firstly, newcomer parties and actors have arisen with nativist features, usually taking a more radical approach than the historical' parties from the period before the electoral earthquakes. Examples of such parties are both parties established by the Czech nativist T. Okamura, the extreme and clerofascist party of M. Kotleba (LSNS) in Slovakia or the Polish party KORWiN. In some cases we have observed the programmatic transformation from (ultra)conservative positions towards a combination of populist and nativist stances (NSi). 
Nevertheless, as a more alarming trend we are observing the 'mainstreamisation' of nativism in ECE. Here, the Hungarian Fidesz and Polish PiS are the clear trend-setters not only in the region, but also in the EU. The Austrian case and the presence and role of the FPÖ in the government also demonstrates these trends. As Mudde (2014) emphasises, in situations where the mainstream political parties adopt extreme right themes including nativist attitudes, fewer opportunities are given to the small 'single-issue' radical parties. In this sense V. Orbán and J. Kaczyński have monopolised the nativist camp in their countries, utilising the salient counter-cosmopolitan preferences (Rensmann, 2012: 64-65).

It's not only in Central Europe that we can observe the negative consequences of poly-crisis and growing disillusionment in the last decade. Such development seems to be similar to the notion of anti-modernity in the second half of the $19^{\text {th }}$ century that grew primarily out of disillusionment with Europe's industrial revolution. Nowadays, we observe similar processes regarding the globalisation, negative consequences of neoliberal reforms and the transition toward an information society (Industry 4.0 etc.). In such a poly-crisis the return of traditionalism, anti-modern and anti-liberal narratives is logical despite the question of whether we face and observe the new anti-modern revolution or a new version of traditional conservative (counter-)revolutions. We are definitely witnessing the 'return' of traditionalism in Central Europe with regional aspects but also national 'specifics' - in Czechia and Slovakia we repeatedly observe a 'coalition' of (former) Communists and pan-Slavic conservative streams (geopolitically oriented on Russia and partly also China, cf. Waisová, 2020); in Hungary and Poland the situation is different regarding the strong actors stressing the important role of history, Christianity/Catholicism and also presenting specific reflections of the interwar period. Nevertheless, a common feature of Central European 'traditionalist' belief is the criticism of the 'ultraliberal' West Europe/EU presented as overall disillusionment with European values - again the typical manifestation of nativism.

This brings us back to the Ruritania concept and to the conflict between two different cultures and societal groups in this region. In my opinion, there exists in ECE a tendency to accept only the 'technical' part of modernisation (industrialisation, welfare), but not the 'ideological' part (liberal democracy). In Ágh's (2019) terminology, the Europeanisation was successful regarding the creation of formal institutions, but failed in its socialisation part. Similarly, Krastev and Holmes (2020) reason that the imitation failed because of the absence of genuine liberal democrats both in the political elite and societies of ECE. Furthermore, the assertive anti-liberal or illiberal actors in the region enforce the turn in the process - the West has to imitate the ECE nativists, if it wants to survive. 
Nativists, labelling themselves patriots, are balancing between nationalism and xenophobia using social chauvinistic rhetoric. They create a world in which it is presumed that 'compatriots take priority' (Bosniak, 1994: 445), and this was also fully proven during the contemporary pandemic. Furthermore, the ECE nativists, often very successful in the domestic political arena, continually strengthen and radicalise their rhetoric and political praxis. This might also be documented in one of the newest examples of such nativist rhetoric, namely the speech of V. Orbán on the occasion of the $100^{\text {th }}$ anniversary of the Trianon Treaty. The analysis of this document would require a separate article, but to summarise the main ideas, Orbán described the Hungarian nation as the steppe tribe that created a Christian state in the Carpathian basin. This state was strong and independent, but under permanent danger from both the East and West. Trianon is presented as the betrayal of the West and an attempt to destroy the Hungarian nation. In his opinion, in 1918 'the thousand-year-old historical Hungary was stabbed in the back by the conspiracies in Budapest' - such rhetoric commemorates the radical ultraconservative and nativist position of German generals Hindenburg and Ludendorff after WWI. Repeatedly, Orbán stresses the Hungarian nation as the manifestation of 'blood and land' (Orbán, 2020). In my opinion, the speech from

300 Sátoraljaújhely presents the peak of nativism in Central Europe so far.

\section{Conclusion}

Nativism and radial right-wing populism are not limited to ECE, but above all the Polish and Hungarian primer make this region kind of a trendsetter. Nevertheless, these parties 'demonstrate some similarities across Europe, displaying a combination of nativism, authoritarianism and populism' (Pirro, 2014: 601). They focus on 'sources of identity such as the ethnic community, they are anti-establishment and thus anti-corruption by definition and they champion anti-Western orientations' (Pirro, 2014: 606).

My first research question asked whether the contemporary nativism in Central Europe grows from visible anti-liberal legacies? As our analysis of the general development of Central European nativist actors demonstrated we can reflect important legacies related with the pre-Communist parochial political culture, as well as the legacies developed within the national-accommodative types of Communist regimes. Naturally, each case study also presents a specific set of 'domestic' characteristic; still, we can distinguish some general regional specifics - especially salient specific ideological cleavages and political preference.

Shaped by specific postcommunist legacies, the conflict axes that these cleavages generate on the demand side can be distinguished from 
Western European contexts. Those legacies engender a significant counter-cosmopolitan segment of the electorate that opposes economic market liberalism, cosmopolitan cultural diversity, and postnational European political integration. (Rensmann, 2012: 68)

The most important negative legacies that might be detected are 'communist-authoritarian and ethnically exclusive societies ... authoritarian conformism, strong support of social cohesion, and ethnic exclusivism' (Rensmann, 2012: 73).

As regards the second research question, we also demonstrated how the nativist agenda became an important part of the Central European mainstream parties' agenda. In some cases, the mainstream party took over the strategy and ideology of smaller nativist parties (PiS; Fidesz, Austrian People's Party), in other cases a new mainstream party was established including the nativist background (Czech ANO, 2011), and we can also observe the combination of both scenarios (Slovakian Smer). Generally, we can speak about the anti-modern and counter-cosmopolitan wave, inset into the all-European and even global nativist revolt.

\section{BIBLIOGRAPHY}

Ágh, Attila (1998): The Politics of Central Europe. London: Sage.

Ágh, Attila (2019): Declining Democracy in East-Central Europe. The Divide in the EU and the Emerging Hard Populism. Cheltenham: Edward Elgar Publishing.

Barša, Pavel and Ondřej Císař (2006): Anarchie a řád ve světové politice: Kapitoly z teorie mezinárodních vztahů. Prague: Portál.

Bergson, Henri (1931/1936): Dvojí pramen mravnosti a náboženství. Prague: Jan Leichter.

Bernik, Ivan (1997): Dvojno odčaranje politike. Ljubljana: FDV.

Bernik, Ivan (2000): Political Culture in Post-socialist Transition. Radical Cultural Change or Adaptation on the Basis of Old Cultural Patterns? Frankfurt/Oder: Viadrina University.

Bosniak, Linda (1994)" "Nativism" and Legitimacy. In: The Transformation of Sovereignty (Proceedings of the Annual Meeting, American Society of International Law, Vol. 88): 440-446. Cambridge: Cambridge University Press.

Buzalka, Juraj (2008): Europeanisation and Post-Peasant Populism in Eastern Europe. Europe-Asia Studies 60 (5): 757-771.

Cabada, Ladislav (2019): Entösterreicherung als kulturelles Fundament und politisches Programm? Zur symbolischen Verräumung österreichischen Symbole und Österreichs in Tschechien. In Cabada, Ladislav (ed.) and Christopher Walsch (ed.), Imaginäre Räume in Zentraleuropa. Kulturelle Transformationen, politische Repräsentationen und trans/nationale Identitätsentwürfe, 111-149. Herne: Gabrielle Schäfer Verlag. 
Cabada, Ladislav (ed.) and Christopher Walsch (ed.) (2019): Imaginäre Räume in Zentraleuropa. Kulturelle Transformationen, politische Repräsentationen und trans/nationale Identitätsentwürfe. Herne: Gabrielle Schäfer Verlag.

Cabada, Ladislav and Christopher Walsch (2017): Od Dunajské federace k Visegrádské skupině ... a zpět. Tradiční a nové formáty středoevropské spolupráce. Prague: Libri.

Cainkar, Louise (2007): Using Sociological Theory to Defuse Anti-Arab/Muslim Nativism and Accelerate Social Integration. Journal of Applied Social Science 1 (1): 7-15.

Corbea-Hoisie, Andrei (2013): Ist "politische Korrektheit" in den Transitionsgesellschaften Mitteleuropas gefragt? Zu einigen rumänischen Beispielen. In Birgit Lermen and Milan Tvrdík (eds.), Brücke zu einem vereinten Europa. Literatur, Werte und Europäische Identität, 229- 237. Prague: Carolinum.

Crepaz, Markus M. L., Jonathan T. Polk, Ryan S. Bakker, and Shane S. Singh (2014): Trust Matters: The Impact of Ingroup and Outrgroup Trust on Nativism and Civicness. Social Science Quarterly 95 (4): 938-959.

Druxes, Helga and Patricia A. Simpson (2016): Pegida as a European Far-Right Populist Movement. German Politics \& Society 34 (4): 1-16.

Fehr, Helmut (2016). Vergeltende Gerechtigkeit - Populismus und Vergangenheitspolitik nach 1989. Opladen - Berlin - Toronto: Verlag Barbara Budrich.

Fink-Hafner, Danica (ed.) and Miro Haček (ed.) (2000): Demokratični prehodi I. Slovenija v primerjavi s srednjeevropskimi postosocialističnimi državami. Ljubljana: FDV.

Friedman, Norman L. (1967): Nativism. Phylon 28 (4): 408-415.

Gellner, Ernest (1983/2008): Nations and Nationalism. Cambridge: Cambridge University Press.

Gellner, Ernest (1998): Language and Solitude. Wittgenstein, Malinowski and the Habsburg Dilemma. Cambridge: Cambridge University Press.

Higham, John (1955/1997): Strangers in the land: Patterns of American nativism: 1860-1925. New York: Atheneum.

Hloušek, Vít and Lubomír Kopeček (2004): Konfliktní demokracie. Moderní masová politika ve střední Evropě. Brno: International Political Science Institute.

Hope, Anthony (1894): The Prisoner of Zenda. London: J. W. Arrowsmith.

Huntington, Samuel P. (1993): The Clash of Civilizations? Foreign Affairs 79 (3): 22-49.

Katerberg, William H. (1995): The Irony of Identity: An Essay on Nativism, Liberal Democracy, and Parochial Identities in Canada and the United States. American Quarterly 47 (3): 493-524.

Kaufmann, Eric (1999): American Exceptionalism Reconsidered: Anglo-Saxon Ethnogenesis in the "Universal" Nation, 1776-1850. Journal of American Studies 33 (3): 437-457.

Kennedy, Paul (1987): The Rise and Fall of the Great Powers. New York: Penguin Random House.

Kitschelt, Herbert (2003): Accounting for Postcommunist Regime Diversity: What Counts a Good Cause? In Grzegorz. Ekiert- Stephen E. Hanson (eds.), Capitalism 
and Democracy in Central and Eastern Europe: the Legacy of Communist Rule, 49-50. Cambridge: Cambridge University Press.

Klíma, Michal (2020): Informal Politics in Post-Communist Europe. Political Parties, Clientelism and State Capture. London and New York: Routledge.

Knoll, Benjamin R. (2013): Implicit Nativist Attitudes, Social Desirability, and Immigration Policy Preferences. The International Migration Review 47 (1): $132-165$.

Kożuchowski, Adam (2013): The Afterlife of Austria-Hungary. The Image of the Habsburg Monarchy in the Interwar Europe. Pittsburgh: University of Pittsburgh Press.

Krastev, Ivan and Stephen Holmes (2020): Světlo, které pohaslo. Vyúčtování. Prague: Karolinum.

Liebhart, Karin (2020): 25 years later - Austria's shift to the populist right: national characteristics of a pan-European trend. Politics in Central Europe 16 (2): 399417.

Mathews, Freya (1999): Becoming Native: An Ethos of Countermodernity II. Worldviews 3 (3): 243-271.

Mudde, Cas (2007): Populist Radical Right Parties in Europe. Cambridge: Cambridge University Press.

Mudde, Cas (2012): The Relationship Between Immigration and Nativism in Europe and North America. Washington: Migration Policy Institute.

Mudde, Cas (2014): Krajnja desnica na europskim izborima 2014. Godine: nešto novoga, mnogo staroga. Političke analize 5 (18): 13-19.

Pirro, Andrea L.P. (2014): Populist Radical Right Parties in Central and Eastern Europe. Government and Opposition 49 (4): 599-628.

Popper, Karl R. (1945/2011): Otevřená společnost a její nepřátelé. Prague: Oikoymenh.

Rensmann, Lars (2012): Volatile Counter-Cosmopolitans: Explaining the Electoral Performance of Radical Right Parties in Poland and Eastern Germany. German Politics \& Society 30 (3): 64-102.

Simcox, Martin (1997): Major Predictors of Immigration Restrictionism: Operationalizing "Nativism". Population and Environment 19 (2): 129-143.

Storey, David (2012): Land, Territory and Identity. In Ian Convery, Gerard Corsane and Peter Davis (eds.) Making Sense of Place. Multidisciplinary Perspectives, 11-22. Woodbridge: Boydel \& Brewer.

Sundstrom, Ronald R. (2013): Sheltering Xenophobia. Critical Philosophy of Race 1 (1): 68-85.

Sztompka, Piotr (1993): Civilisational Incompetence - The Trap of Post-communist Societies. Zeitschrift für Soziologie 22 (2): 85-95.

Šori, Iztok (2015): Za narodov blagor: skrajno desni populizem v diskurzu stranke Nova Slovenija. Časopis za kritiko znanosti, domišljijo in novo antropologijo 43 (260): 104-117.

Ther, Philipp (2014): Die neue Ordnung auf dem alten Kontinent. Eine Geschichte des neoliberalen Europa. Berlin, Suhrkamp Verlag.

Tismaneanu, Vladimir (1998): Fantasies of Salvation: Democracy, Nationalism, and Myth in Post-Communist Europe. Princeton: Princeton University Press. 
Waisová, Śárka (2020): Central Europe in the New Millenium: The New Great Game? US, Russian, and Chinese Interests in Czechia, Hungary, Poland and Slovakia. Revista UNISCI (54): 2-48.

Weidinger, Bernhard (2017): Equal before God, and God Alone: Cultural Fundamentalism, (Anti-)Egalitarianism, and Christian Rhetoric in Nativist Discourse from Austria and the United States. Journal of Austrian-American History 1 (1): $40-68$.

\section{SOURCES}

Ágh, Attila (2020): The clash of "Europeanization" and "Traditionalization" narratives in Hungary: East-Central Europe in the process of reinventing the past (preprint). Accessible at https://www.researchgate.net/publication/342734259_ The_clash_of_Europeanization_and_Traditionalization_narratives_in_ Hungary_East-Central_Europe_in_the_process_of_reinventing_the_past_preprint_for_a_volume_about_the_narratives_in_the_EU, 11. 7. 2020.

Anderson, Robert (2016): Orban and Kaczynski's 'cultural counter-revolution' will devour its children. IntelliNews, 25. 10. 2016. Accessible at https://www.intellinews.com/visegrad-orban-and-kaczynski-s-cultural-counter-revolution-willdevour-its-children-108836/, 23. 7. 2020.

Cambridge Words (2017): Cambridge Dictionary's Word of the Year 2017. Accessible at https://dictionaryblog.cambridge.org/2017/11/29/cambridge-dictionarys-word-of-the-year-2017/, 20. 7. 2020.

Matulík, Rostislav (2019): Proč se George Soros stal univerzálním nepř́itelem krajní pravice? Czech Radio, 14. 9. 2019. Accessible at https://plus.rozhlas.cz/proc-segeorge-soros-stal-univerzalnim-nepritelem-krajni-pravice-8075525, 11. 7. 2020.

Mudde, Cas (2017): Why nativism, not populism, should be declared word of the year. The Guardian, 7 December 2017. Accessible at https://www.theguardian.

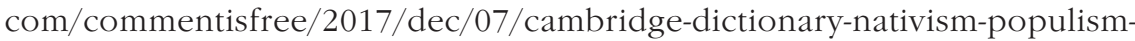
word-year, 20. 7. 2020.

Orbán, Viktor (2020): Prime Minister Viktor Orbán's commemoration speech, 6. 6. 2020. Accessible at http://abouthungary.hu/speeches-and-remarks/primeminister-viktor-orbans-commemoration-speech-trianon/, 20. 7. 2020. 